\title{
Vegetation patterns maintained by cattle grazing on a degraded mountain pasture
}

\section{Journal Article}

\section{Author(s):}

Jewell, Peter L.; Güsewell, Sabine; Berry, Nigel R.; Käuferle, Dominik; Kreuzer, Michael; Edwards, Peter J.

Publication date:

2005-12

Permanent link:

https://doi.org/10.3929/ethz-b-000035213

Rights / license:

In Copyright - Non-Commercial Use Permitted

Originally published in:

Botanica Helvetica 115(2), https://doi.org/10.1007/s00035-005-0727-6 


\title{
Vegetation patterns maintained by cattle grazing on a degraded mountain pasture
}

\author{
Peter L. Jewell' ${ }^{\text {, Sabine Güsewell }}{ }^{1}$, Nigel R. Berry ${ }^{2,3}$, Dominik Käuferle ${ }^{1}$, \\ Michael Kreuzer ${ }^{2}$ and Peter J. Edwards ${ }^{1^{*}}$ \\ 1 Geobotanical Institute ETH Zurich, CHN, CH-8092 Zurich; \\ e-mail: peter.edwards@env.ethz.ch \\ 2 Institute of Animal Sciences ETH Zurich, CH-8092 Zurich \\ 3 Present address: Swiss Federal Research Station for Agricultural Economics and \\ Engineering, CH-8356 Tänikon \\ * Editor: Pascal Vittoz
}

Manuscript accepted 10 June 2005

\begin{abstract}
Jewell P.L., Güsewell S., Berry N.R., Käuferle D., Kreuzer M. and Edwards P.J. 2005. Vegetation patterns maintained by cattle grazing on a degraded mountain pasture. Bot. Helv. 115: 109-124.

In southern Switzerland the use of mountain pastures for cattle has been in decline since the 19th century, promoting the dominance of unpalatable grasses and shrubs. In an attempt to improve pasture quality, 80 Scottish Highland cattle were introduced to a 73ha grazing area on acidic soils at 1400-1800 $\mathrm{m}$ a.s.l. To assess how this management might affect the vegetation, we surveyed the plant species composition, soil chemistry and spatial patterns of cattle grazing. Large parts of the pasture were low-productive Nardetum grassland or Callunetum heathland. Patches of more productive and nutrient-rich grassland occurred on less acidic soils with higher total P concentration and lower C:N, C:P and N:P ratios. Grazing by cattle focused on these patches, while N. stricta grasslands and heathlands were hardly used. Historical evidence suggests that these patterns of cattle use are similar to those in the past. We conclude that the current grazing regime is unlikely to produce a significant change in vegetation composition and pasture quality.
\end{abstract}

Key words: Habitat use, Nardetum, nutrient limitation, soil chemistry, subalpine grassland, vegetation map.

\section{Introduction}

Mountain grasslands in the Alps range are amongst the oldest agricultural production systems of the world, some of them having been used as summer pastures for domestic livestock for thousands of years (Bätzing 2003). To maintain their productivity, management of these pastures must be carefully adapted to local conditions, as 
inadequate management increases the risks of soil erosion, mud-slides or avalanches (Tasser et al. 2003; Müller et al. 2004) and promotes the spread of unpalatable grasses, forbs, shrubs or ferns (Spatz and Papachristou 1999; Krahulec et al. 2001). The choice of an adequate stocking rate is further complicated by the tendency of animals to use the pasture area heterogeneously, so that some parts are overused and others neglected (Moog et al. 2002; Matejková et al. 2003; Müller et al. 2003). Traditional agriculture in the Alps therefore involved numerous practices to avoid local overuse of pastures and ensure that they were exploited as uniformly as possible (Bätzing 2003). In the 19th and 20th century, however, economic and social changes led to the depopulation of Alpine communities, the breakdown of traditional forms of exploitation, and the abandonment of many alpine meadows and pastures (Tasser and Tappeiner 2002; Bätzing 2003). This development was particularly pronounced in areas with naturally poor soils, such as the granitic massifs of the southern Swiss Alps.

The declining use of mountain pastures in the Alps has led to changes in their vegetation and has caused a loss of agricultural resources and biodiversity (Dullinger et al. 2003; Müller et al. 2003). There is now increasing concern that these changes may reduce the attractiveness of the Alpine landscape to tourists, who are currently a major source of income in this region (Hunziker 1995). In response to these concerns, grazing by cattle or sheep has been reintroduced experimentally in many places; in some cases the aim has been to enhance botanical diversity (Barbaro et al. 2001; Krahulec et al. 2001), while in others it has been to develop forms of pasture use that are economically viable yet ecologically sustainable (Estermann et al. 2001, 2003; Berry et al. 2001, 2002; Mayer et al. 2003). To understand how these new practices may affect the vegetation of mountain ecosystems, we need to study spatial patterns of pasture use by freeranging livestock (Erzinger 1996; Matejková et al. 2003). Such an approach contrasts with classical grazing studies that are based on comparisons between grazed and ungrazed areas (Tracy and Frank 1998; Hellström et al. 2003) or among areas with differing grazing regimes (Hackl et al. 2000; Bardgett et al. 2001).

This paper is concerned with the effects of reintroducing cattle in a mountain pasture in southern Switzerland. Agricultural use of this site had been in decline for more than 100 years, and by 1990 it had been virtually abandoned. In 1994 a herd of Scottish Highland cattle was introduced in a new attempt to use the area productively. The new scheme had two aims: to produce beef of Alpine origin as a 'niche' product (see www.primalp.ethz.ch), and to improve pasture quality by restoring the former grazing intensity. Because Scottish Highland cattle can use herbage of low nutritional quality (Berry et al. 2002) it was expected that they would be able to cover their energy requirements by feeding on the rather poor forage which was available; it was also hoped that, in doing so, they would improve the quality of the pasture, reducing the dominance of shrubs and promoting more nutritious grass species. To assess whether these vegetation changes were likely to occur, we investigated the distribution of vegetation types across the pasture area, their plant species composition and biomass, their relation to soil chemistry, and their utilisation by the cattle in 1996 and 1998.

\section{Methods}

Study site and its management history

The study site 'Alpe Nisciora' is a pasture of 73 ha at $1400-1800 \mathrm{~m}$ a.s.l. on the south-eastern flank of Monte Gradiccioli in southern Switzerland (46 $04^{\prime}$ N; $8^{\circ} 52^{\prime}$ E; 


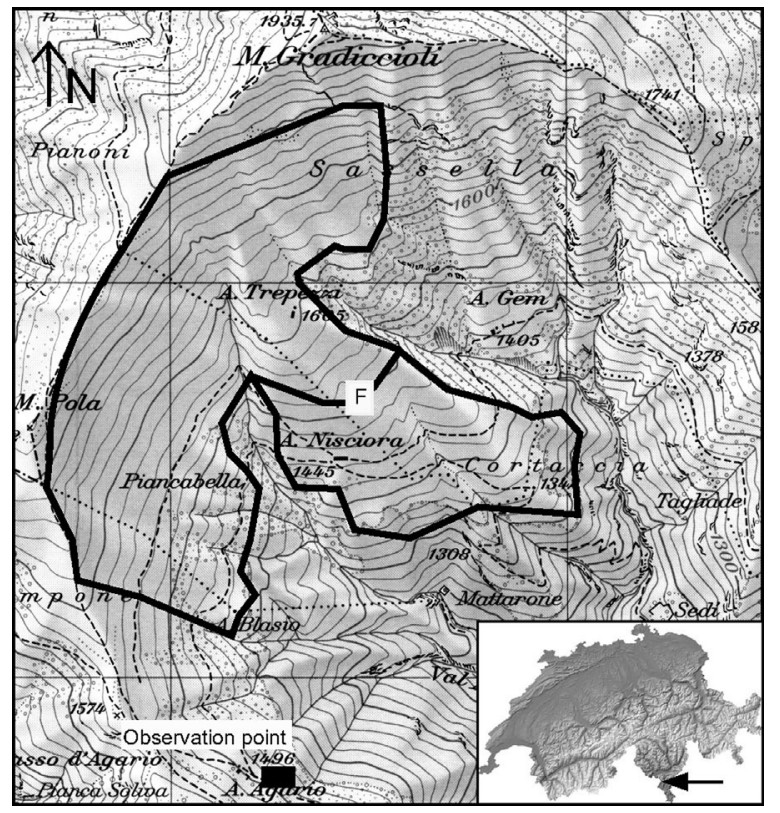

Fig. 1. Map of the pasture area (Mount Gradiccioli) showing the topography (elevation contour lines), the location of Alpe Nisciora, the boundary of the vegetation map (Fig. 2), the fence (F) which subdivided the pasture into two paddocks in 1996 (Fig. 4), and the point from where cattle observations were made. The inset shows the location of the site in southern Switzerland.

Fig. 1). The natural altitudinal limit of tree growth is around $1700 \mathrm{~m}$, with beech (Fagus sylvatica) as the treeline species (Ellenberg 1996), but due to the long history of grazing, the entire study area above $1400 \mathrm{~m}$ is now free of forest vegetation.

The climate is Insubrian, with a mean ambient air temperature during the grazing season (June-October) of $13{ }^{\circ} \mathrm{C}$ and a mean monthly precipitation of $300 \mathrm{~mm}$ (Berry et al. 2002). A substantial part of the annual precipitation falls in a few extremely intense rain events than can cause severe soil erosion (personal observation of the authors). Between these rain spells, there can be pronounced drought periods. The underlying rock area consists of mixed biotite-plagioclase gneiss (Reinhard et al.1962). Soils range from acidic brown-earth to cryptopodzol (a regional soil type characterised by strong acidity and a high content of recalcitrant organic matter; Blaser et al. 1997). A fine, silty texture with strong water repellence makes these soils particularly prone to desiccation and erosion under the prevailing irregular rainfall regime.

Pollen analyses suggest that agricultural use in the Ticino region began around 5000 BP (Burga 1988; Tinner et al. 1999). Between the 9th and 12th century AD, considerable forest clearance occurred, and new settlements were established in upland regions (Zoller 1960). The pastures on Monte Gradiccioli were probably established at about this time. The existence on Alpe Nisciora of trackways, boundary posts and several agricultural buildings (some now in ruins) all indicate the former economic importance of the site. However, parish reports from the community of Mugena mention that low 
productivity, declining economic interest, and the resulting lack of proper management were already considered serious problems in the 19th century, despite attempts to counteract this trend through regulations (L. Saltini, unpublished report based on the archives of Mugena). During the 20th century, the number of cattle using Alpe Nisciora fell from over 60 to only 6 in 1994, and grazing by goats was completely discontinued (unpublished data from the archives of Mugena).

Since 1994, Scottish Highland cattle (40-60 cows and their calves) have been kept on Alpe Nisciora for approximately 100 days per year. The exact grazing regime varies from year to year, as decided by pasture tenants. In 1996 (the first year of observations), the pasture was subdivided into two parts by an old fence at approximately 1700 $\mathrm{m}$ a.s.l. (Fig. 1); the animals grazed in the lower eastern part (18 ha, below $1700 \mathrm{~m})$ from 30 May to 19 July and were then moved to the upper western part (33 ha, mostly above $1700 \mathrm{~m}$ ), where they remained until the end of September. In 1998, the pasture was not subdivided and was grazed in two periods, one from late July until mid-August and the second from mid-September until mid-November (cattle were moved to another pasture between these periods). The pasture was not fertilised directly, but cattle were supplied with mineral licks (around $5012-\mathrm{kg}$ tablets per year) to ensure an adequate supply of essential mineral elements (composition per kg: $65 \mathrm{~g} \mathrm{P}, 135 \mathrm{~g} \mathrm{Ca}$ and $85 \mathrm{~g} \mathrm{Na}$; Multiforsa AG, Steinhausen, Switzerland). A variable fraction of the minerals consumed in this way by the cattle (depending on their current nutrient status) is transferred to the soil with cattle dung and urine (Estermann et al. 2001). Another nutrient input to the site is from atmospheric $\mathrm{N}$ deposition, which in this region amounts to 30-40 kg ha ${ }^{-1} \mathrm{a}^{-1}$ (Flückiger and Braun 1998).

\section{Vegetation and soil sampling}

In summer 1998, 94 relevé plots $(1 \mathrm{~m} \times 1 \mathrm{~m})$ were established on the pasture (excluding shrub-dominated areas). Seventy plots were located at c. 100-m intervals along eight transects running parallel to the contours of the slope at $50-\mathrm{m}$ intervals of altitude (Fig. 2). The other 24 plots were selected deliberately in order to sample vegetation types that occurred only locally; their minimum distance was $30 \mathrm{~m}$, except for two plots that were $18 \mathrm{~m}$ apart. Plant species composition was recorded by visually estimating percentage cover in July 1998 (nomenclature: Lauber and Wagner 1996). Weighted average ecological indicator values were calculated for each plot (Landolt 1977). A vegetation map was drawn by visual interpretation of an aerial photograph from 1995 and using field records made in 2000 with the aid of a GPS.

Vegetation biomass was measured by clipping 14 randomly selected plots in August 1998 and a further 20 plots in August 2000. The freshly harvested material was weighed in the field, and 100 -g subsamples were dried at $70^{\circ} \mathrm{C}$ for $48 \mathrm{~h}$ in order to calculate the dry mass of plant material. In 2000, the subsamples were sorted into live and dead material before drying, so as to determine the fraction of living biomass. The biomass from three plots per vegetation type was analysed for $\mathrm{N}$ and $\mathrm{P}$ concentrations using a modified Kjeldahl digestion ( $1 \mathrm{~h}$ digestion at $420{ }^{\circ} \mathrm{C}$ with $98 \% \mathrm{H}_{2} \mathrm{SO}_{4}$ and a copper sulphate-titanium oxide catalyst) followed by colorimetric analysis (FIA analyser, Tecator, Höganäs, SE).

Soil samples were taken in 1998 at 82 of the plots from $0-5,5-10$ and $10-15 \mathrm{~cm}$ below the soil surface using a $5 \mathrm{~cm}$ diameter corer. Samples were air-dried, ground and analysed for total $\mathrm{C}$ and $\mathrm{N}$ concentration (CN-2000, Leco corporation, St. Joseph, Mi, USA), total $\mathrm{P}$ concentration (Kjeldahl method as described for plant biomass), and $\mathrm{pH}$ (in $0.01 \mathrm{M} \mathrm{CaCl}_{2}$ ). 


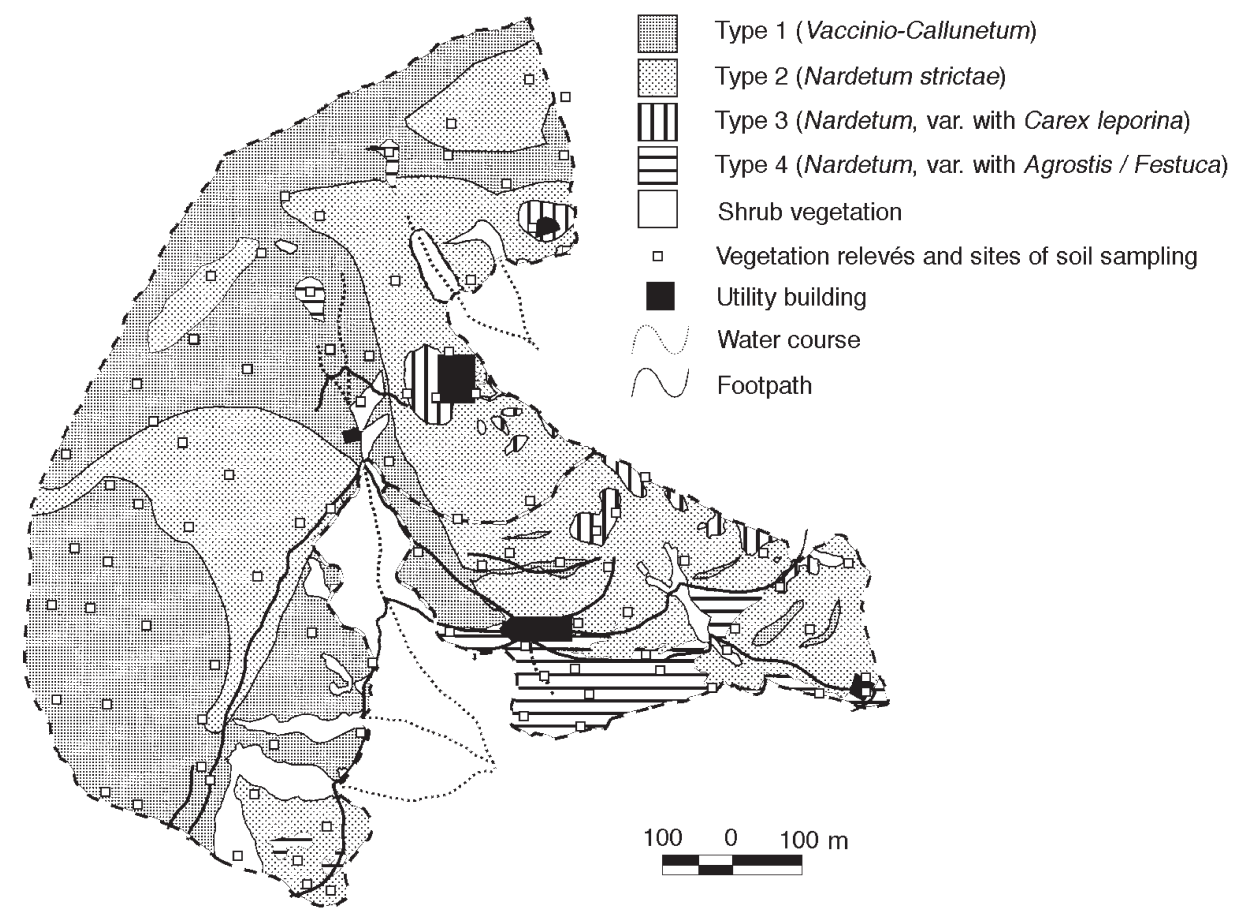

Fig. 2. Vegetation map of the pasture area showing the distribution of the four main vegetation types (Tab. 1) in relation to topography (Fig. 1) and landscape features as well as the position of the 94 vegetation relevés. "Shrub vegetation" (not included in the vegetation survey) mostly consisted of Alnus viridis and Cytisus scoparius.

\section{Observations of cattle grazing}

The spatial distribution and activity of cattle were observed from a ridge overlooking the pasture (Fig. 1). With the aid of binoculars fitted with a distance recorder and compass (Leica Geovit, Heerbrugg, $\mathrm{CH}$ ) we recorded the positions of cattle on a map (1:2'500) to a precision of $\pm 10 \mathrm{~m}$, and classified their activity as grazing, moving or other. In 1996, observations were made every $3 \mathrm{~h}$ between 06.00 and 21.00 on eight days (10-11 June, 4-5 July, 21-22 July and 5-6 August), yielding 48 distribution maps. In 1998, observations were made every 2 h on 22-24 July, 7-9 August and 4-5 November (only until 19.00), yielding 52 distribution maps. The spatial distribution of cattle dung was also mapped in 1996 and 1998, but since the large-scale patterns of grazing and excretion were similar (Edwards et al. 2004), only the grazing data are considered here.

To calculate grazing intensity, the 100 point distribution maps were pooled and converted into a probability density distribution for the entire study area using the Kernel estimator with a cell size of $1 \mathrm{~m}^{2}$ and a search radius of $20 \mathrm{~m}$ (GIS programme ArcInfo). Grazing intensity at each relevé plot was derived from this map. We only analysed grazing patterns in this study because the spatial distribution of cattle dung and of grazing were similar across the pasture. 
Tab. 1. Species composition of the four main pasture vegetation types of Alpe Nisciora, given as mean $\pm \mathrm{SD}$ of percentage cover and as frequency of occurrence $(\mathrm{r}=0-10 \%, \mathrm{I}=10-20 \%$, $\mathrm{II}=21-40 \%, \mathrm{III}=41-60 \%, \mathrm{IV}=61-80 \%, \mathrm{~V}=80-100 \%$ of the relevés) for the most frequent species ( $\geq 2 \%$ mean cover or $\geq 20 \%$ frequency in at least one vegetation type). All other species found in the vegetation survey are listed at the bottom of the table with the vegetation type(s) in which they occurred.

\begin{tabular}{|c|c|c|c|c|c|c|c|c|}
\hline \multirow[b]{2}{*}{ Calluna vulgaris } & \multicolumn{2}{|c|}{$\begin{array}{l}1 \text { Callunetum } \\
n=31 \text { relevés }\end{array}$} & \multicolumn{2}{|l|}{$\begin{array}{l}2 \text { Nardetum } \\
n=32 \text { relevés }\end{array}$} & \multicolumn{2}{|c|}{$\begin{array}{l}3 \text { Nardetum var. } \\
\text { Carex leporina } \\
n=8 \text { relevés }\end{array}$} & \multicolumn{2}{|c|}{$\begin{array}{l}4 \text { Nardetum var. } \\
\text { Agrostis-Festuca } \\
n=23 \text { relevés }\end{array}$} \\
\hline & $19.5 \pm 13.8$ & $\mathrm{~V}$ & $2.0 \pm 3.9$ & II & & & $0.9 \pm 2.5$ & I \\
\hline Vaccinium vitis-idaea & $4.2 \pm 3.1$ & $\mathrm{~V}$ & $1.4 \pm 2.4$ & III & & & $0.4 \pm 1.0$ & I \\
\hline Vaccinium myrtillus & $4.1 \pm 4.1$ & IV & $2.5 \pm 3.1$ & III & & & $0.2 \pm 0.6$ & I \\
\hline Carex pilulifera & $3.2 \pm 2.8$ & $\mathrm{~V}$ & $4.3 \pm 2.9$ & $\mathrm{~V}$ & & & $0.2 \pm 0.9$ & $\mathrm{r}$ \\
\hline Danthonia decumbens & $1.7 \pm 2.4$ & III & $0.5 \pm 1.0$ & II & & & & \\
\hline Majanthemum bifolium & $0.7 \pm 1.1$ & III & $0.8 \pm 1.1$ & III & & & & \\
\hline Crocus albiflorus & $0.5 \pm 0.7$ & II & $0.4 \pm 0.6$ & II & & & & \\
\hline Leontodon helveticus & $0.1 \pm 0.5$ & $\mathrm{r}$ & $0.3 \pm 0.7$ & II & & & & \\
\hline Nardus stricta & $17.1 \pm 11.1$ & $\mathrm{~V}$ & $55.9 \pm 18.2$ & $\mathrm{~V}$ & $21.6 \pm 15.7$ & $\mathrm{~V}$ & $4.7 \pm 7.1$ & III \\
\hline Carex leporina & & & $0.5 \pm 1.5$ & I & $24.0 \pm 9.6$ & & $2.0 \pm 3.9$ & II \\
\hline Prunella vulgaris & & & & & $4.7 \pm 10.4$ & II & & \\
\hline Rumex acetosella & $0.1 \pm 0.4$ & $\mathrm{r}$ & $0.3 \pm 0.8$ & I & $5.1 \pm 4.0$ & $\mathrm{~V}$ & $4.3 \pm 6.7$ & III \\
\hline Agrostis tenuis & $0.3 \pm 0.9$ & I & $0.6 \pm 1.1$ & I & $4.4 \pm 5.2$ & IV & $14.9 \pm 16.8$ & $\mathrm{~V}$ \\
\hline Festuca rubra & $3.8 \pm 4.3$ & IV & $2.4 \pm 4.0$ & III & $4.4 \pm 6.5$ & III & $12.3 \pm 13.8$ & $\mathrm{~V}$ \\
\hline Pteridium aquilinum & $0.3 \pm 1.5$ & $\mathrm{r}$ & & & & & $3.1 \pm 6.4$ & II \\
\hline Urtica dioica & & & & & & & $2.4 \pm 8.6$ & I \\
\hline Lolium perenne & & & & & & & $2.2 \pm 8.1$ & \\
\hline Trifolium repens & & & & & & & $0.7 \pm 1.4$ & II \\
\hline Galeopsis tetrahit & & & & & & & $0.5 \pm 1.1$ & II \\
\hline Anthoxanthum odoratum & $1.9 \pm 1.9$ & IV & $1.6 \pm 2.1$ & III & $1.4 \pm 3.8$ & I & $2.1 \pm 4.1$ & III \\
\hline Deschampsia flexuosa & $4.5 \pm 2.4$ & $\mathrm{~V}$ & $2.6 \pm 2.3$ & $\mathrm{r}$ & $1.9 \pm 2.4$ & III & $1.2 \pm 2.6$ & II \\
\hline Potentilla erecta & $1.3 \pm 1.6$ & III & $2.0 \pm 2.5$ & IV & $0.3 \pm 0.8$ & I & $0.9 \pm 1.3$ & III \\
\hline Rubus idaeus & & I & & II & & I & & II \\
\hline Thymus praecox & $0.1 \pm 0.3$ & $\mathrm{r}$ & & & $0.3 \pm 0.8$ & I & $1.0 \pm 2.5$ & II \\
\hline Carex fritchii & $1.2 \pm 2.0$ & II & $0.3 \pm 1.0$ & I & & & $0.7 \pm 2.0$ & I \\
\hline Phyteuma betonicifolium & $1.0 \pm 1.3$ & III & $0.4 \pm 0.6$ & II & & & $0.3 \pm 0.7$ & I \\
\hline Galium anisophyllum & $0.3 \pm 0.8$ & I & $1.7 \pm 0.5$ & I & & & $0.9 \pm 1.9$ & II \\
\hline Festuca ovina & $0.7 \pm 1.3$ & II & $0.4 \pm 1.3$ & I & & & $0.1 \pm 0.4$ & $\mathrm{r}$ \\
\hline
\end{tabular}




\section{Data analysis}

To determine the main vegetation types in the area, plant species occurring in only one plot were excluded and cover values were square-root transformed, after which vegetation relevés were grouped by means of a cluster analysis based on a matrix of similarity ratios (van der Maarel 1979) and using the minimum variance algorithm of MULVA 5 (Wildi and Orloci 1996). Four groups were recognised as this was the most obvious group structure in the dendrogram. A principal coordinates analysis was run on the same matrix of similarity ratios to represent vegetation patterns in an ordination.

Soil chemistry was described by 21 variables: total $\mathrm{C}, \mathrm{N}$ and $\mathrm{P}$ concentrations, C:N ratio, $\mathrm{C}: \mathrm{P}$ ratio, $\mathrm{N}: \mathrm{P}$ ratio and $\mathrm{pH}$, each for three soil layers. Data on $\mathrm{P}$ concentration required log-transformation, whereas the other variables were normally distributed without transformation. A principal components analysis (PCA) was carried out to visualise correlations among soil variables (JMP version 3.22, SAS Institute, Carey, NC, USA).

To analyse relationships between vegetation and site conditions, mean values of soil chemistry and ecological indicator values were calculated for each vegetation type identified by the cluster analysis; differences among vegetation types were tested with a oneway Anova after checking that there was no spatial autocorrelation in the residuals.

Grazing intensity had a strongly skewed distribution with $35 \%$ zero values. Therefore, intensity values were converted into a nominal variable with three classes: no grazing (intensity $=0$ ), light grazing (intensity $\leq$ median of non-zero values) and heavy grazing (intensity $>$ median of non-zero values). We determined the fraction of plots of each vegetation type that was ungrazed, lightly grazed or heavily grazed and applied Pearson's Chi square to test whether grazing intensity differed among vegetation types.

\section{Results}

Four main vegetation types were identified by a cluster analysis of the vegetation relevés (Tab. 1). Their spatial distribution across the pasture was related to topography and pasture management (Tab. 2a; Fig. 2). Type 1 (31 relevés) was heathland co-dominated by Calluna vulgaris, Vaccinium myrtillus, $V$. vitis-idaea together with Nardus stricta and Deschampsia flexuosa; it can be attributed to the phytosociological association Vaccinio-Callunetum Bük. 42 (Mucina et al. 1993; Pott 1995). It occurred above $1650 \mathrm{~m}$ a.s.l. and in the western section of the pasture, i.e. in the areas most remote from the former stable, mainly on steep slopes with a step-like microtopography. Type 2 (32 relevés), covering about $70 \%$ of the area, had a similar species composition as Type 1 ,

Tab. 1 (cont.)

Additional species: Achillea millefolium (4), Astrantia minor (1,2), Campanula scheuchzeri $(1,2,4)$, Carex pallescens $(1,2,4)$, Cerastium arvense $(3,4)$, Cerastium fontanum $(3,4)$, Chaerophyllum hirsutum (2), Cirsium acaule (1,2,4), Crepis aurea (1,2), Cruciata glabra (4), Cytisus scoparius $(1,4)$, Festuca glauca $(2,4)$, Genista tinctoria $(1,2,4)$, Gentiana kochiana $(1,2)$, Geranium sylvaticum $(1,2)$, Hieracium pilosella $(1,4)$, Hieracium sp. $(1,2,4)$, Homogyne alpina $(1,2)$, Leontodon helveticus $(1,2)$, Lolium perenne (4), Lotus corniculatus $(1,4)$, Luzula multiflora $(1,2,4)$, Molinia caerulea $(1,2)$, Phleum alpinum $(2,4)$, Phleum pratense $(1,2,3,4)$, Poa annua $(3,4)$, Polygala chamaebuxus $(1,2)$, Ranunculus acris $(1,4)$, Rhododendron ferrugineum $(1,4)$, Soldanella alpina $(1,2)$, Solidago virgaurea (2), Stellaria graminea $(1,4)$, Trifolium pratense ssp. alpinum $(1,2)$, Viola hirta $(1,4)$. 
Tab. 2. Ecological characteristics, soil chemistry and cattle use of the four main vegetation types occurring at Alpe Nisciora. Data are means \pm standard deviations of $n$ plots $(n$ given at the bottom of the table). In (a), 'total standing crop' includes living and dead material, whereas 'aboveground biomass' includes only living material; $\mathrm{N}$ and $\mathrm{P}$ concentrations were determined in the above-ground living biomass; indicator values (Landolt 1977) for nutrient availability $(\mathrm{N})$ and soil $\mathrm{pH}(\mathrm{R})$ range from 1 (low) to 5 (high). In (b) and (c), total C, $\mathrm{N}$ and $\mathrm{P}$ concentrations are given as percentages of soil dry mass. For each variable, means of the four vegetation types were compared pairwise with Tukey-Kramer tests; means without common superscripts differ significantly ( $\mathrm{P}<$ $0.05)$. In (d), the intensity of cattle grazing is given as the percentage of plots that were not grazed, lightly grazed (less than median of non-zero plots) or heavily grazed (more than median).

\begin{tabular}{|c|c|c|c|c|}
\hline & 1 Callunetum & 2 Nardetum & $\begin{array}{l}3 \text { Nardetum var. } \\
\text { Carex leporina }\end{array}$ & $\begin{array}{l}4 \text { Nardetum var. } \\
\text { Agrostis-Festuca }\end{array}$ \\
\hline \multicolumn{5}{|l|}{ (a) Topography and vegetation } \\
\hline Slope $(\%)^{\#}$ & $41.2 \pm 13.3^{c}$ & $33.9 \pm 10.5^{b c}$ & $8.3 \pm$ & $28.3 \pm 23.9^{b}$ \\
\hline Species number $\left(\mathrm{m}^{-2}\right)^{*}$ & $13.0 \pm 2.78^{b}$ & $9.8 \pm 3.45^{\circ}$ & $5.4 \pm 1.92^{\mathrm{a}}$ & $9.2 \pm 5.08^{\mathrm{ac}}$ \\
\hline Vegetation cover $(\%)^{*}$ & $74.1 \pm 15.6^{\mathrm{ab}}$ & $81.0 \pm 9.1^{\mathrm{b}}$ & $65.8 \pm 25.2^{\mathrm{a}}$ & $67.5 \pm 19.7^{\mathrm{a}}$ \\
\hline Total standing crop $\left(\mathrm{g} \mathrm{m}^{-2}\right)^{\S}$ & $704.0 \pm 452.9^{\mathrm{a}}$ & $1003.8 \pm 436.0^{\mathrm{b}}$ & $534.2 \pm 179.5^{\mathrm{a}}$ & $401.1 \pm 155.8^{\mathrm{a}}$ \\
\hline Aboveground biomass $\left(\mathrm{g} \mathrm{m}^{-2}\right)^{\S}$ & $136.1 \pm 36.3^{b}$ & $175.5 \pm 29.4^{\mathrm{ab}}$ & $234.8 \pm 21.6^{\mathrm{a}}$ & $225.4 \pm 19.9^{\mathrm{a}}$ \\
\hline $\mathrm{N}$ concentration $\left(\mathrm{mg} \mathrm{g}^{-1}\right)^{+}$ & $12.4 \pm 1.30^{\mathrm{a}}$ & $16.3 \pm 2.13^{\mathrm{b}}$ & $12.8 \pm 0.24^{\mathrm{ab}}$ & $13.6 \pm 0.93^{\mathrm{ab}}$ \\
\hline$P$ concentration $\left(\mathrm{mg} \mathrm{g}^{-1}\right)^{+}$ & $0.8 \pm 0.03^{\mathrm{b}}$ & $1.0 \pm 0.11^{\mathrm{b}}$ & $1.8 \pm 0.02^{\mathrm{a}}$ & $1.6 \pm 0.15^{\mathrm{a}}$ \\
\hline $\mathrm{N}: \mathrm{P}$ ratio (by mass) ${ }^{+}$ & $16.1 \pm 1.29^{\mathrm{b}}$ & $16.7 \pm 0.35^{\mathrm{b}}$ & $7.2 \pm 0.06^{\mathrm{a}}$ & $8.6 \pm 0.24^{\mathrm{a}}$ \\
\hline $\mathrm{N}$ indicator value* & $1.9 \pm$ & $2.1 \pm$ & $2.1 \pm$ & $2.6 \pm$ \\
\hline $\mathrm{R}$ indicator value* & $1.8 \pm$ & $2.0 \pm$ & $2.0 \pm 0.2^{\mathrm{ab}}$ & $2.4 \pm$ \\
\hline \multicolumn{5}{|l|}{ (b) Soil (0-5 cm depth) } \\
\hline $\mathrm{pH}\left(0.01 \mathrm{M} \mathrm{CaCl}_{2}\right)^{\#}$ & $3.64 \pm 0.14^{\mathrm{ab}}$ & $3.58 \pm 0.14^{\mathrm{a}}$ & $3.68 \pm 0.18^{\mathrm{ab}}$ & $3.77 \pm 0.32^{\mathrm{a}}$ \\
\hline $\mathrm{C}(\%)^{\#}$ & $16.98 \pm 3.54^{\mathrm{b}}$ & $16.98 \pm 3.28^{\mathrm{b}}$ & $12.43 \pm 2.55^{\mathrm{a}}$ & $12.83 \pm 3.86^{\mathrm{a}}$ \\
\hline $\mathrm{N}(\%)^{\#}$ & $1.26 \pm 0.24^{\mathrm{ab}}$ & $1.31 \pm 0.20^{\mathrm{b}}$ & $1.03 \pm 0.21^{\mathrm{ab}}$ & $1.08 \pm 0.32^{\mathrm{a}}$ \\
\hline $\mathrm{P}(\%)^{\#}$ & $0.09 \pm 0.02^{b}$ & $0.10 \pm 0.03^{b}$ & $0.15 \pm 0.05^{\mathrm{a}}$ & $0.14 \pm 0.06^{\mathrm{a}}$ \\
\hline $\mathrm{C}: \mathrm{N}$ ratio ${ }^{\#}$ & $13.39 \pm 0.64^{c}$ & $12.94 \pm 0.91^{\mathrm{a}}$ & $12.06 \pm 0.87^{\mathrm{ab}}$ & $11.86 \pm 1.17^{\mathrm{b}}$ \\
\hline C:P ratio ${ }^{\#}$ & $184.60 \pm 37.15^{\mathrm{b}}$ & $171.41 \pm 42.47^{\mathrm{b}}$ & $91.44 \pm 36.14^{\mathrm{a}}$ & $102.59 \pm 40.13^{a}$ \\
\hline \multicolumn{5}{|l|}{ (c) Soil (10-15 cm depth) } \\
\hline $\mathrm{pH}\left(0.01 \mathrm{M} \mathrm{CaCl}_{2}\right)^{\#}$ & $3.94 \pm 0.10^{\mathrm{ab}}$ & $3.87 \pm 0.13^{\mathrm{b}}$ & $4.00 \pm 0.18^{\mathrm{ab}}$ & $4.02 \pm 0.25^{\mathrm{a}}$ \\
\hline $\mathrm{C}(\%)^{\#}$ & $11.22 \pm 3.09^{b}$ & $11.19 \pm 2.68^{\mathrm{b}}$ & $4.63 \pm 1.59^{\mathrm{a}}$ & $7.08 \pm 2.57^{\mathrm{a}}$ \\
\hline $\mathrm{N}(\%)^{\#}$ & $0.85 \pm 0.22^{b}$ & $0.87 \pm 0.19^{b}$ & $0.44 \pm 0.14^{\mathrm{a}}$ & $0.62 \pm 0.19^{\mathrm{a}}$ \\
\hline $\mathrm{P}(\%)^{\#}$ & $0.07 \pm 0.02^{b}$ & $0.08 \pm 0.02^{\mathrm{b}}$ & $0.10 \pm 0.04^{\mathrm{ab}}$ & $0.10 \pm 0.06^{\mathrm{a}}$ \\
\hline $\mathrm{C}: \mathrm{N}$ ratio ${ }^{\#}$ & $13.18 \pm 0.80^{\mathrm{b}}$ & $12.74 \pm 0.91^{\mathrm{b}}$ & $10.58 \pm 1.51^{\mathrm{a}}$ & $11.21 \pm 1.36^{\mathrm{a}}$ \\
\hline C:P ratio ${ }^{\#}$ & $153.42 \pm 39.76^{\mathrm{b}}$ & $153.26 \pm 45.72^{b}$ & $58.01 \pm 32.25^{\mathrm{a}}$ & $82.39 \pm 41.22^{a}$ \\
\hline \multicolumn{5}{|l|}{ (d) Cattle grazing } \\
\hline Not grazed (\% of plots) ${ }^{\#}$ & 56 & 50 & 0 & 5 \\
\hline Lightly grazed (\% of plots) ${ }^{\#}$ & 32 & 27 & 71 & 11 \\
\hline Heavily grazed (\% of plots) & 12 & 23 & 29 & 84 \\
\hline
\end{tabular}

Sample size $n$ for vegetation types $1-4:{ }^{*} n=31,32,8,23 ;{ }^{\S} n=12,8,6,8 ;{ }^{+} n=3 ;{ }^{\#} n=30,24,7$ and 21 


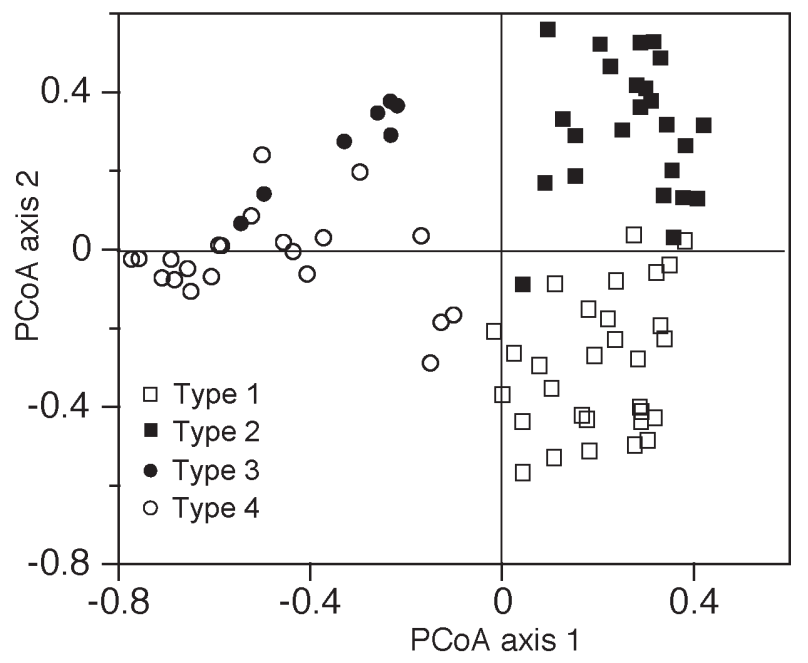

Fig. 3. Ordination of the vegetation relevés based on principal coordinates analysis (PCoA). The first two ordination axes are shown, representing $19.3 \%$ and $13.4 \%$ of total variation in species data, respectively. Symbols for relevés indicate the vegetation types (Tab. 1 and Fig. 2).

but Nardus stricta was absolutely dominant; we attribute it to the Nardetum strictae (Rübel 1911) Br.-Bl. 1949 em. Oberd. 1950 (Pott 1995). Type 3 (8 relevés) was a speciespoor variety of the Nardetum strictae, co-dominated by Carex leporina and Nardus stricta. It occurred on flat areas around the former stable and in small level patches (often at the top of ridges), where cattle tended to rest. Type 4 (23 relevés) was an intermediate between the Nardetum and Poion alpinae communities, characterised by the dominance of Agrostis capillaris, Festuca rubra or, in some plots, Pteridium aquilinum. This vegetation type covered the lowermost part of the pasture area below a path that was presumably the main access route in the past.

In a PCoA ordination (Fig. 3), the distinction between vegetation types 1-2 and 3-4 (axis 1) explained $19 \%$ of the variation in species composition, followed by the separation of types 1 and 2 on axis 2 (13\% of variation), and finally the separation of types 3 and 4 on axis 3 (5.7\% of variation, not shown).

The four vegetation types differed in species richness and productivity (Tab. 2a). The Callunetum (type 1) had the highest species diversity and large standing crop, but living biomass was small. The typical Nardetum strictae (type 2) had the greatest vegetation cover and standing crop of the four types, but more than $80 \%$ of this material was dead. The species-poor Nardetum with Carex leporina (type 3) had a small standing crop but a large fraction of living material, suggesting high biomass production. Stands dominated by Agrostis capillaris, Festuca rubra or Pteridium aquilinum (type 4) had a low standing crop, but ecological indicator values indicate more fertile and less acidic soils than in the other vegetation types; species richness varied considerably among relevés (Tab. 2a).

Soil chemistry of vegetation types 1 and 2 differed significantly from that of types 3 and 4, with a lower $\mathrm{pH}$, greater $\mathrm{C}$ and $\mathrm{N}$ concentrations, lower $\mathrm{P}$ concentrations, and higher C:N, C:P and N:P ratios in types 1 and 2 (Tab. 2b,c). These differences were con- 

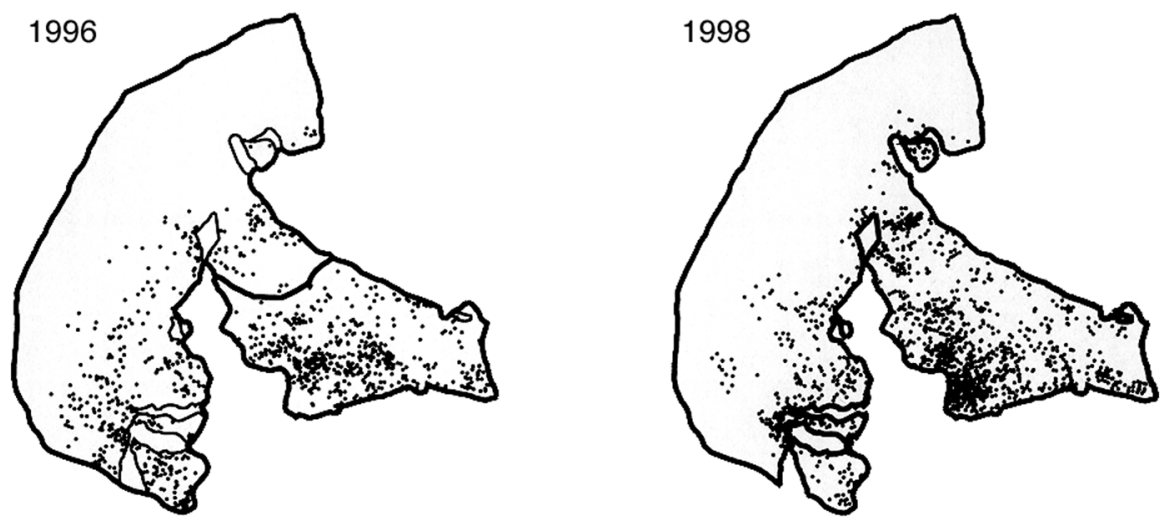

Fig. 4. Point distribution maps of cattle grazing, (a) during summer 1996 (pasture subdivided into two paddocks by a fence) and (b) during summer 1998 (free ranging). Each point corresponds to one observation of a grazing animal.

sistent across soil layers, except that the strong $\mathrm{P}$ enrichment of the soil in vegetation type 3 was restricted to the $0-5 \mathrm{~cm}$ layer (Tab. $2 \mathrm{~b}$ ). There were no significant differences in soil chemistry between vegetation types 1 and 2, nor between types 3 and 4 .

Cattle grazing focused on the lower parts of the pasture area (Fig. 4), so that most of the area was grazed only lightly (about $40 \%$ of the total area) or not at all (about $50 \%$ of the area). Vegetation dominated by Agrostis capillaris, Festuca rubra or Pteridium aquilinum (type 4) was used most intensely, with many plots being heavily grazed, whereas most plots of Nardetum with Carex leporina (type 3) were only lightly grazed, and most plots of vegetation types 1 and 2 were not grazed at all (Tab. 2d; Pearson's Chi square $=35.7, \mathrm{P}<0.001$ ). The difference in grazing intensity between types 3 and 4 was related to the fact that type 3 was mainly used for resting, causing the soil to be heavily loaded with cattle dung (pers. observation).

Grazing patterns changed with time: at the beginning of the season, cattle fed almost exclusively on the stands dominated by Agrostis capillaris and Festuca rubra (type 4) at the bottom of the pasture area. When this herbage became exhausted, cattle spread out and also grazed the vegetation dominated by Nardus stricta (type 2). Towards the end of the season, however, the animals remained near the buildings and water points, even though very little herbage remained in these areas.

\section{Discussion}

Vegetation patterns in relation to site conditions

The vegetation of Alpe Nisciora presents a sharp visual contrast between large areas dominated by dwarf shrubs or tussocks of Nardus stricta (vegetation types 1 and 2), small 'camp areas' with dense swards of Carex leporina (type 3), and 'grazing lawns' dominated by Agrostis tenuis and Festuca rubra (type 4). Despite the contrasting vegetation structure, plant species composition was rather similar across the pasture 
(Tab. 1). The most frequent species were all indicative of acidic, nutrient-poor soils (Nardo-Callunetea); typical species of nutrient-rich mountain grasslands (PolygonoTrisetion and Poion alpinae) were rare even in the areas used most intensively by the cattle, probably due to the strong acidity and the unfavourable hydrological properties of the soil.

The more productive vegetation types 3 and 4 were primarily characterised by a greater availability of phosphorus, as indicated by plant and soil $\mathrm{P}$ concentrations. The mean plant $\mathrm{N}: \mathrm{P}$ ratios suggest that biomass production was $\mathrm{N}$-limited in vegetation types 3 and $4(\mathrm{~N}: \mathrm{P}<10)$ but $\mathrm{P}$-limited in vegetation types 1 and $2(\mathrm{~N}: \mathrm{P}>15$; Güsewell and Koerselman 2002; Tessier and Raynal 2003). Besides a low supply of phosphate from the parent rock material (Newman 1995) and P exports with animal products (Newman 1997; Edwards et al. 2004), the current high atmospheric N deposition may cause or strengthen P limitation in upland grasslands (Johnson et al. 1999, Turner et al. 2003). This may apply to Alpe Nisciora, where the atmospheric input of $\mathrm{N}$ is high due to the proximity of the heavily industrialised region of Milan (110 km to the south). These high $\mathrm{N}$ inputs together with the particular chemistry of cryptopodzolic soils (Blaser et al.1997) may also explain why the soils of Alpe Nisciora have rather low C/N ratios compared with similar vegetation in other regions (Gisi and Oertli 1981; Aerts et al. 1995; Müller et al. 2003; Turner et al. 2003), and why N availability did not seem to differ among vegetation types.

The balance between grasses and dwarf shrubs in upland pastures depends on the disturbance regime, with dwarf shrubs being weakened and grasses being promoted by trampling and defoliation (Alonso and Hartley 1998; Hartley and Amos 1999; Alonso et al. 2001). This explains why the dwarf shrubs on Alpe Nisciora occurred mostly on steep slopes where cattle have created steps by moving along fixed paths. On these slopes, the shrubs grew mainly on the almost vertical 'risers' between the steps, where they benefitted not only from an absence of trampling but also from relatively open microsites for seed germination (in strong contrast to the dense Nardus swards elsewhere). Increased $\mathrm{N}$ and/or $\mathrm{P}$ availability generally promotes the dominance of grasses over dwarf shrubs in heathlands (Heil and Diemont 1983; Aerts and Berendse 1988; Aerts et al. 1995; Roem et al. 2002; Tomassen et al. 2003). On Alpe Nisciora, however, dwarf-shrub dominated (type 1) and Nardus-dominated (type 2) vegetation did not differ in nutrient concentrations in plants and soil, supporting the idea that their distribution was primarily determined by the interaction between topography and cattle use.

Vegetation patterns in relation to grazing

Cattle mainly grazed vegetation types 3 and 4 in the lower and flatter areas of Alpe Nisciora. Less than $10 \%$ of the pasture area was grazed very intensively, while more than $50 \%$ was hardly used at all. Highly selective habitat utilisation is typical of extensively managed pastures (van den Bos and Bakker 1990; Adler et al. 2001) where animals concentrate their feeding on herbage of high digestibility and nutrient content (Mayer et al. 2003; Rook et al. 2004). Topography may be another important factor determining habitat use (Bailey et al. 2003). On Alpe Nisciora, the most nutritious vegetation types were also those that occurred in flatter areas, so that either food quality or topography may have determined the selective pasture use.

Habitat use often follows pronounced seasonal patterns (Putman et al. 1987; Gander et al.2003). In our study, the preference for vegetation types 3 and 4 was so strong that it prevailed throughout the grazing season. However, there was increased use of Nardus vegetation in mid-summer, probably because the food resources in the pre- 
ferred areas were depleted (Berry et al.2002). Greater selectivity by cattle at the beginning or at the end of the summer than in the middle corresponds to observations in other areas (Matejková et al. 2003).

Selective feeding is regarded as an important mechanism through which grazing can increase the species diversity of pasture vegetation (Rook et al. 2004). However, the effect of grazing on species diversity can be positive or negative depending on the productivity of the vegtation (Olff and Ritchie 1998; Proulx and Mazumder 1998; Stammel et al. 2003), on the interaction between grazing patterns and pre-existing vegetation patterns (Adler et al. 2001), and on the scale at which diversity is assessed (Dullinger et al. 2003). In the Austrian Alps, grazing increased landscape-scale species diversity by maintaining a mosaic of mountain plant communities, whereas there was no consistent effect on within-community diversity (Dullinger et al. 2003). On Alpe Nisciora, grazing appeared to have little effect on species richness: the intensively used vegetation types 3 and 4 were not more species-rich (per $\mathrm{m}^{2}$ ) than types 1 and 2, nor did they contribute substantially to the total species richness of the pasture: of the 60 species recorded in our survey, only one species occurred exclusively in vegetation type 3 and six species in type 4, mainly in a groundwater seepage area with moister and less acidic soil. Species diversity would of course change if the abandonment of grazing were to lead to a complete re-forestation of the area.

Although no detailed records are available of the former vegetation of Alpe Nisciora, we suppose that the present vegetation patterns are largely the result of the longterm pastoral use. The presence of forest on nearby mountains indicates that Alpe Nisciora was forested before its conversion to pasture, except for the uppermost parts. Grazing probably started in these naturally open areas and was progressively extended downwards through forest clearance (Bätzing 2003). If so, the upper parts of the pasture were the main grazing area in the past, and nutrient exports with dairy products and meat would have impoverished their soils before those in the lower parts of the pasture. Erosion may also have been promoted by deforestation and trampling, causing a downward transport of topsoil. Grazing pressure in the upper parts probably declined markedly when the pasture was extended downwards and when management became less intense (as mentioned for the 19th century in the archives of the local community), promoting the expansion of Nardus stricta and dwarf shrubs (Welch and Scott 1995; Grant et al. 1996).

The effects of selective grazing on the productivity and food quality of pastures are often mediated by positive feedbacks (Wilson and Agnew 1992; Adler et al.2001; Gillet et al. 2002). These occur because palatable species tend to be more tolerant of defoliation and more responsive to nutrient supply than unpalatable ones, and are therefore promoted if grazing causes a local acceleration of nutrient turnover (Diaz et al. 2001; Cingolani et al. 2005). On Alpe Nisciora, the most heavily grazed vegetation of type 4 consisted of relatively fast-growing grass and forb species, which certainly benefit from the excreta dropped by cattle (Wilson and Agnew 1992). Thus, patterns in topography, soil chemistry, selective grazing and resting behaviour act together in maintaining the present vegetation pattern on Alpe Nisciora.

\section{Perspectives for a regeneration of the pasture}

When the Scottish Highland cattle were introduced on Alpe Nisciora in 1994, it was expected that the relatively high stocking rate would force the cattle to use the entire pasture, promoting grazing-tolerant, productive grass species and reducing shrubs (Spatz and Papachristou 1999). However, this expectation was not fulfilled because the 
animals concentrated their grazing on a small proportion of the pasture and hardly used the heathland vegetation. After ten grazing seasons (autumn 2003), vegetation composition was still essentially the same as in 1996 when the first survey was made (D. Käuferle, unpublished thesis). An inspection of aerial photographs also leads to the conclusion that there has been little change in the vegetation since 1945. As proposed above, this is unlikely to change in the future because the vegetation is determined by the interaction between topography and ecosystem processes, including grazing. For similar reasons, Matejková et al. (2003) also found little effect of grazing on the vegetation of a mountain grassland. Pasche et al. (2004) observed no relationship between the long-term spread of Rhododendron ferrugineum in species-rich subalpine meadows and grazing intensity. Grazing experiments in which the vegetation changed markedly within a few years generally took place at sites where the dominant species were both preferred by the grazers and grazing-intolerant; a typical example is Phragmites australis in wetlands (Rozé 1993; Vulink et al. 2000).

In conclusion, our survey has shown that vegetation patterns on Alpe Nisciora correspond to differences in soil nutrient availability. Biomass production appears to be phosphorus-limited over large parts of the area; together with soil acidity, this favours species-poor vegetation of low nutritional quality. The pasture is used heterogeneously by the Scottish Highland cattle, which prefer to feed in the flatter areas with higher herbage quality. Their selective feeding behaviour (together with the mineral food supplement) enables these animals to meet their nutritional requirements (Berry et al. 2002), but it also acts to maintain the existing vegetation patterns (Edwards et al. 2004). It is even questionable to what extent a management regime ensuring a more homogeneous use of the pasture, such as rotational grazing, would lead to a general improvement in herbage quality, given the adverse soil properties. Thus, the degradation of this pasture might be an irremediable outcome of a long grazing history under naturally unfavourable conditions.

\section{Zusammenfassung}

Viele Alpweiden der Südschweiz (Tessin) wurden seit dem 19. Jahrhundert immer extensiver genutzt, so dass Borstgras (Nardus stricta), Zwergsträucher (Calluna vulgaris, Vaccinium spp.) und Gebüsche (Alnus viridis, Cytisus scoparius) sich ausgebreitet haben. Als Versuch, die Qualität einer Alpweide im Südtessin zu verbessern, wurde seit 1994 eine 73 ha grosse Weidefläche auf 1400-1800 m ü.M. während 100 Tagen pro Jahr mit 80 Schottischen Hochlandrindern bestossen. Um die Auswirkung der Bewirtschaftung zu beurteilen, wurden 1998 Vegetationsaufnahmen und Bodenanalysen durchgeführt, und die räumlich-zeitlichen Muster der Weidenutzung durch die Rinder wurden in den Sommern 1996 und 1998 beobachtet. Grosse Teile der Weidefläche hatten einen sehr sauren Boden ( $\mathrm{pH}$ 3.6-3.8) und waren mit nährstoffarmen Borstgrasrasen (Nardetum) oder Zwergstrauchheiden (Callunetum) bedeckt. Der limitierende Nährstoff schien dort Phosphor (P) zu sein. Ertragreichere Weidetypen befanden sich kleinräumig auf Böden mit höherer P-Konzentration und tieferem C:N-, C:P- und N:P-Verhältnis. Die Rinder beweideten vor allem diese Stellen und nutzten die Borstgrasrasen und Heiden kaum; auch die Unterteilung der Weidefläche in zwei Koppeln durch einen Zaun im Jahr 1996 beeinflusste das selektive Weideverhalten nur wenig. Historische Quellen weisen darauf hin, dass bereits im 19. Jahrhundert aufgrund geringer Weidepflege ähnliche Beweidungsmuster bestanden. Unsere Ergebnisse lassen vermuten, 
dass die 1994 eingeführte Bewirtschaftungsform nicht genügt, um die Vegetationszusammensetzung und Weidequalität wesentlich zu verändern.

We thank G. Berardi for allowing us to study his herd of cattle and to use the facilities of Alpe Gem as a base during field work as well as for providing technical support during the first phase of the project. L Saltini searched the archives of the community of Mugena for historical information on the use of the pasture. U. Jewell and A. Scherer kindly assisted with the field work, and R. Trachsler with nutrient analyses. The research was funded by ETH Zürich as part of the PRIMALP research collaboration.

\section{References}

Adler P.B., Raff D.A. and Lauenroth W.K. 2001. The effect of grazing on the spatial heterogeneity of vegetation. Oecologia 128: 465-479.

Aerts R. and Berendse F. 1988. The effect of increased nutrient availability on vegetation dynamics in wet heathlands. Vegetatio 76: 63-69.

Aerts R., Huiszoon A., van Oostrum J.H.A., van De Vijver C.A.D.M. and Willems J.H. 1995. The potential for heathland restoration on formerly arable land at a site in Drenthe, The Netherlands. J. Appl. Ecol. 32: 827-835.

Alonso I. and Hartley S.E. 1998. Effects of nutrient supply, light availability and herbivory on the growth of heather and three competing grass species. Plant Ecol. 137: 203-212.

Alonso I., Hartley S.E. and Thurlow M. 2001. Competition between heather and grasses on Scottish moorlands: interacting effects of nutrient enrichment and grazing regime. J. Veg. Sci. 12:249-260.

Bailey D.W., Keil M.R. and Rittenhouse L.R. 2003. Daily movement patterns of hill climbing and bottom dwelling cows. J. Range Manage. 57: 20-28.

Barbaro L., Dutoit T. and Cozic P. 2001. A six-year experimental restoration of biodiversity by shrub-clearing and grazing in calcareous grasslands of the French Prealps. Biodivers. Conserv. 10: 119-135.

Bardgett R.D., Jones A.C., Jones D.L., Kemmitt S.J., Cook R. and Hobbs P.J. 2001. Soil microbial community patterns related to the history and intensity of grazing in sub-montane ecosystems. Soil Biol. Biochem. 33: 1653-1664.

Bätzing W. 2003. Die Alpen - Entstehung und Gefährdung einer europäischen Kulturlandschaft. 2. Aufl. C.H. Beck, München.

Berry N.R., Jewell P.L., Sutter F., Edwards P.J. and Kreuzer M. 2001. Effect of concentrate on nitrogen turnover and excretion of $\mathrm{P}, \mathrm{K}, \mathrm{Na}, \mathrm{Ca}$ and $\mathrm{Mg}$ in lactating cows rotationally grazed at high altitude. Livestock Prod. Sci. 71: 261-275.

Berry N.R., Jewell P.L., Sutter F., Edwards P.J. and Kreuzer M. 2002. Selection, intake and excretion of nutrients by Scottish Highland suckler beef cows and calves, and Brown Swiss dairy cows in contrasting Alpine grazing systems. J. Agric. Sci. 139: 437-453.

Blaser P., Kernebeek P., Tebbens L., van Breemen N. and Luster J. 1997. Cryptopodzolic soils in Switzerland. Eur. J. Soil Sci. 48: 411-423.

Burga C.A. 1988. Swiss vegetation history during the last 18000 years. New Phytol. 110: 581-602.

Cingolani A.M., Posse G. and Collantes M.B. 2005. Plant functional traits, herbivore selectivity and response to sheep grazing in Patagonian steppe grasslands. J. Appl. Ecol. 42: 50-59.

Diaz S., Noy-Meir I. and Cabido M. 2001. Can grazing response of herbaceous plants be predicted from simple vegetative traits? J. Appl. Ecol. 38: 497-508.

Dullinger S., Dirnböck T., Greimler J. and Grabherr G. 2003. A resampling approach for evaluating effects of pasture abandonment on subalpine plant species diversity. J. Veg. Sci. 14:243-252.

Edwards P. J., Berry N.R., Güsewell S., Jewell P.L. and Kreuzer M. 2004. Long-term effects of cattle grazing upon the nutrient status of alpine pastures. In: Lüscher A., Jeangros B., Kessler W. Huguenin O., Lobsiger M., Millar N. and Suter D. (eds.) Land Use Systems in Grassland Dominated Regions. Vdf, Zürich, 302-304.

Ellenberg H. 1996. Vegetation Mitteleuropas mit den Alpen. 5. Aufl. Eugen Ulmer, Stuttgart.

Erzinger S. 1996. Einfluss von Schottischen Hochlandrindern auf eine montane Weide im oberen Tösstal. Bull. Geobot. Inst. ETH 62: 47-60. 
Estermann B.L., Wettstein H.R., Sutter F. and Kreuzer M. 2001. Nutrient and energy conversion of grass-fed dairy and suckler beef cattle kept indoors and on high altitude pasture. Anim. Res. 50: 477-493.

Estermann B.L., Wettstein H.R., Sutter F., Erdin D. and Kreuzer M. 2003. Effect of calving period on herbage intake and nutrient turnover of Simmental and Angus suckler cows with Angus sired calves grazing subalpine and alpine pastures. Livestock Production Science 79:169-182.

Flückiger W. and Braun S. 1998. Nitrogen deposition in Swiss forests and its possible relevance for leaf nutrient status, parasite attacks and soil acidification. Environ. Pollut. 102 (S1): 69-76.

Gander A., Rockmann A., Strehler C. and Güsewell S. 2003. Habitat use by Scottish Highland cattle in a lakeshore wetland. Bull. Geobot. Inst. ETH 69: 3-16.

Gillet F., Besson O. and Gobat J.-M. 2002. PATUMOD: a compartment model of vegetation dynamics in wooded pastures. Ecol. Modell. 147: 267-290.

Gisi U. and Oertli J.J. 1981. Ökologische Entwicklung im Brachland verglichen mit Kulturwiesen I. Physikalisch-chemische Veränderungen im Boden. Acta Oecol. 2: 7-21.

Grant S.A., Torvell L., Sim E.M., Small J.L. and Armstrong R.H. 1996. Controlled grazing studies on Nardus grassland: effects of between-tussock sward height and species of grazer on Nardus utilization and floristic composition in two fields in Scotland. J. Appl. Ecol. 33: 1053-1064.

Güsewell S. and Koerselman W. 2002. Variation in nitrogen and phosphorus concentrations of wetland plants. Persp. Ecol. Evol. Syst. 5: 37-61.

Hackl E., Zechmeister-Boltenstern S. and Kandeler E. 2000. Nitrogen dynamics in different types of pasture in the Austrian Alps. Biol. Fertil. Soils 32: 321-327.

Hartley S.E. and Amos L. 1999. Competitive interactions between Nardus stricta L. and Calluna vulgaris (L.) Hull: the effect of fertilizer and defoliation on above- and below-ground performance. J. Ecol. 87: 330-340.

Heil G.W. and Diemont W.H. 1983. Raised nutrient levels change heathland into grassland. Vegetatio 53: 113-120.

Hellström K., Huhta A.-P., Rautio P., Tuomi J., Oksanen J. and Laine K. 2003. Use of sheep grazing in the restoration of semi-natural meadows in northern Finland. Appl. Veg. Sci. 6: 45-52.

Hunziker M. 1995. The spontaneous reafforestation in abandoned agricultural lands: perception and aesthetic assessment by locals and tourists. Landsc. Urban Plan. 31:339-410.

Johnson D., Leake J.R. and Lee J.A. 1999. The effects of quantity and duration of simulated pollutant nitrogen deposition on root-surface phosphatase activities in calcareous and acid grasslands: a bioassay approach. New Phytol. 141: 433-442.

Krahulec F., Skálová H., Herben T., Hadincová V., Wildová R. and Pechácková S. 2001. Vegetation changes following sheep grazing in abandoned mountain meadows. Appl. Veg. Sci. 4: 97-102.

Landolt E. 1977. Ökologische Zeigerwerte zur Schweizer Flora. Veröff. Geobot. Inst. ETH Zurich 64: $1-208$

Lauber K. and Wagner G. 1996. Flora Helvetica. Haupt, Bern.

Matejková I., van Diggelen R. and Prach K. 2003. An attempt to restore a central European species-rich mountain grassland through grazing. Appl. Veg. Sci. 6: 161-168.

Mayer A.C., Stockli V., Huovinen C., Konold W., Estermann B.L. and Kreuzer M. 2003. Herbage selection by cattle on sub-alpine wood pastures. Forest Ecol. Man. 181:39-50.

Moog D., Poschlod P., Kahmen S. and Schreiber K.-F. 2002. Comparison of species composition between different grassland management treatments after 25 years. Appl. Veg. Sci. 5: 99-106.

Mucina L., Grabherr G. und Ellmauer T. 1993. Die Pflanzengesellschaften Österreichs. Teil I Anthropogene Vegetation. Fischer, Jena.

Müller P., Güsewell S. und Edwards P.J. 2003. Einfluss von Boden und Bewirtschaftung auf die Artenvielfalt der Vegetation auf Alpweiden im Glarnerland. Bot. Helv. 113: 15-36.

Müller P., Güsewell S. und Tanner K.-M. 2004. Integration von ökologischem Wissen in die Raumplanung. Das Beispiel Alpweiden im Glarnerland. GAIA 13: 131-139.

Newman E.I. 1995. Phosphorus inputs to terrestrial ecosystems. J. Ecol. 83: 713-726.

Newman E.I. 1997. Phosphorus balance of contrasting farming systems, past and present. Can food production be sustainable? J. Appl. Ecol. 34: 1334-1347.

Olff H. and Ritchie M.E. 1998. Effects of herbivores on grassland diversity. Trends Ecol. Evol. 13: 261-165.

Pasche F., Armand M., Gouaux P., Lamaze T. and Pornon A. 2004. Are meadows with high eco- 
logical and patrimonial value endangered by heathland invasion in the French central Pyrenees? Biol. Conserv. 118: 101-108.

Pott R. 1995. Die Pflanzengesellschaften Deutschlands. 2. Aufl. Ulmer, Stuttgart.

Proulx M. and Mazumder A. 1998. Reversal of grazing impact on plant species richness in nutrient-poor vs. nutrient-rich ecosystems. Ecology 79: 2581-2592.

Putman R.J., Pratt R.M., Ekins J.R. and Edwards P.J. 1987. Food and feeding behaviour of cattle and ponies in the New Forest, Hampshire. J. Appl. Ecol. 24: 369-380.

Reinhard M., Bächlin R., Graeter P., Lehner P. und Spicher A. 1962. Geologischer Atlas der Schweiz, 9. Ed. Kümmerly \& Frey, Bern.

Roem W.J., Klees H. and Berendse F. 2002. Effects of nutrient addition and acidification on plant species diversity and seed germination in heathland. J. Appl. Ecol. 39: 937-948.

Rook A.J., Dumont B., Isselstein J., Osoro K., WallisDeVries M.F., Parente G. and Mills J. 2004 Matching type of livestock to desired biodiversity outcomes in pastures - a review. Biol. Conserv. 119: 137-150.

Rozé F. 1993. Successions végétales après pâturage extensif par des chevaux dans une roselière. Bulletin d'Ecologie 24: 203-209.

Spatz G. and Papachristou T.G. 1999. Ecological strategies of shrubs invading extensified grasslands: their control and use. In: Grasslands and Woody Plants in Europe. Proceedings of the Intern. Occasional Symposium of the European Grassland Federation, Thessalonik, 27.-29.5.1999, 27-36.

Stammel B., Kiehl K. and Pfadenhauer J. 2003. Alternative management on fens: response of vegetation to grazing or mowing. Appl. Veg. Sci. 6: 245-254.

Tasser E., Mader M. and Tappeiner U. 2003. Effects of land use in alpine grasslands on the probability of landslides. Basic. Appl. Ecol. 4: 271-280.

Tasser E. and Tappeiner U. 2002. Impact of land use changes on mountain vegetation. Appl. Veg. Sci. 5: 173-184.

Tessier J.T. and Raynal D.Y. 2003. Use of nitrogen to phosphorus ratios in plant tissue as an indicator of nutrient limitation and nitrogen saturation. J. Appl. Ecol. 40: 523-534.

Tinner W., Hubschmid P., Wehrli M., Ammann B. and Conedera M. 1999. Long-term forest fire ecology and dynamics in southern Switzerland. J. Ecol. 87: 273-289.

Tomassen H.B.M., Smolders A.J.P., Lamers L.P.M. and Roelofs J.G.M. 2003. Stimulated growth of Betula pubescens and Molinia caerulea on ombrotrophic bogs: role of high levels of atmospheric N deposition. J. Ecol. 91: 357-370.

Tracy B.F. and Frank D.A. 1998. Herbivore influence on soil microbial biomass and nitrogen mineralization in a northern grassland ecosystem: Yellowstone National Park. Oecologia 114: $556-562$.

Turner B.L., Chudek J.A., Whitton B.A. and Baxter R. 2003. Phosphorus composition of upland soils polluted by long-term atmospheric nitrogen deposition. Biogeochem. 65: 259-274.

Van den Bos J. and Bakker J.P. 1990. The development of vegetation patterns by cattle grazing at low stocking density in the Netherlands. Biol. Conserv. 51: 263-272.

Van der Maarel E. 1979. Transformation of cover-abundance values in phytosociology and its effects on community similarity. Vegetatio 139: 97-114.

Vulink J.T., Drost H.J. and Jans L. 2000. The influence of different grazing regimes on Phragmitesand shrub vegetation in the well-drained zone of a eutrophic wetland. Appl. Veg. Sci. 3: 73-80

Welch D. and Scott D. 1995. Studies in the grazing of heather moorland in northeast Scotland. VI. 20-year trends in botanical composition. J. Appl. Ecol. 32: 596-611.

Wildi O. and Orloci L. 1996. Numerical Exploration of Community Patterns. SPB Academic Publishing, The Hague.

Wilson J.B. and Agnew A.D.Q. 1992. Positive-feedback switches in plant communities. Adv. Ecol. Res. 23: 263-336.

Zoller H. 1960. Pollenanalytische Untersuchungen zur Vegetationsgeschichte der insubrischen Schweiz. Denkschr. Schweiz. Nat.forsch. Ges. 83: 45-156. 